\title{
EVALUATION OF ATTENUATION OF IMPACT ON BENTONITE-BASED BUFFER UNDER CONSTRUCTION
}

\author{
Ryoichi MASUDA ${ }^{1}$, Hidekazu ASANO ${ }^{2}$, Hiroyuki TADA ${ }^{3}$, Tsuyoshi NISHIMURA ${ }^{4}$, \\ Kiyoshi AMEMIYA ${ }^{5}$ and Hideo KOMINE 6 \\ ${ }^{1}$ Member of JSCE, Advanced Waste Systems Research Project, RWMC \\ (No.15, Mori Bldg, 2-8-10, Toranomon, Minato-ku, Tokyo 105-0001, Japan) \\ E-mail:masuda@rwmc.or.jp \\ 2 MA, Advanced Waste Systems Research Project, RWMC \\ (No.15, Mori Bldg, 2-8-10, Toranomon, Minato-ku, Tokyo 105-0001, Japan) \\ ${ }^{3}$ Member of JSCE, MA, Advanced Waste Systems Research Project, RWMC \\ (No.15, Mori Bldg, 2-8-10, Toranomon, Minato-ku, Tokyo 105-0001, Japan) \\ ${ }^{4}$ Member of JSCE, MA, Hazama Corporation (2-2-5, Toranomon, Minato-ku, Tokyo 105-8479, Japan) \\ ${ }^{5}$ Member of JSCE, Ph.D. , Hazama Corporation (2-2-5, Toranomon, Minato-ku, Tokyo 105-8479, Japan) \\ ${ }^{6}$ Member of JSCE, Associate Professor, Dept.of Civil Eng., University of Ibaraki \\ (4-12-1, Nakanarusawa, Hitachi, Ibaraki 316-8511, Japan)
}

\begin{abstract}
In in-situ compaction method, where the material is directly compacted in the disposal pit, possible damage to the surrounding rock and waste package due to the impact of compaction are issues of concern. While an evaluation of the effect of impact is necessary, the analysis based on Finite Elemental Method (FEM) has not yet been achieved with sufficient accuracy. Experiments were carried out and data obtained for the acceleration damping characteristics of the buffer material. The results were then used with an analytical model in order to improve the accuracy of the analysis. By comparing this with data obtained from full-scale experiment, it was possible to confirm the validity of the analysis that takes acceleration damping characteristics.
\end{abstract}

Key Words : engineered barrier system, buffer, in-situ compaction method, bentonite, Rayleigh damping, geological disposal, high level radioactive waste

\section{INTRODUCTION}

It is specified in Japan that high-level radioactive waste (HLW) arising from nuclear power generation should be disposed in bedrock at a depth of 300 meters or more. The vitrified HLW, encapsulated in overpacks, is emplaced in the repository and barriers (called buffers) consisting of clay-based material are placed around the waste. The buffers are expected to retard nuclide migration and physically protect the overpack. At present, highly compacted bentonite is considered to be the most favorable candidate for buffer material. The continuing development of buffer construction technologies is important in terms of the safety assurance of geological disposal. Currently, research and development of several technologies are in progress ${ }^{1)}$.

In the in-situ compaction technique, developed based on soil compaction technology, the material is directly compacted in the disposal pit. Features include a highly flexible aggregate composition, simple equipment and close contact of the buffer material with the host rock. For the establishment of the construction technology, necessary data concerning the compaction characteristics of the bentonite-based material have been accumulated and relevant expertise is being developed ${ }^{2), 3), 4)}$. It has been demonstrated that $0.15 \mathrm{Ec}$ or greater compaction energy per strike is required (Ec stands for standard compaction workload, prescribed as "Standard Proctor"; $\left.1 \mathrm{Ec}=5.51 \times 10^{2} \mathrm{~kJ} / \mathrm{m}^{3}\right)$. A compaction system with free drops of several tons of weight is being studied ${ }^{2,5)}$.

Particular characteristics of this technique, including possible damage to the surrounding rock, overpack and vitrified waste due to compaction impact, are matters for concern, and a compaction impact effect analysis for the surrounding regions is there- 


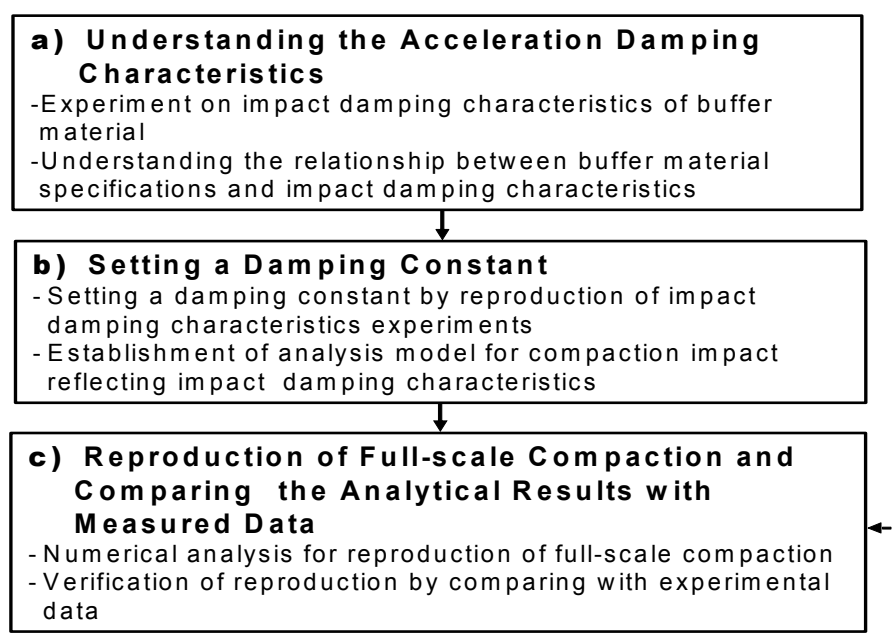

Fig.1 Flow Diagram of the Study

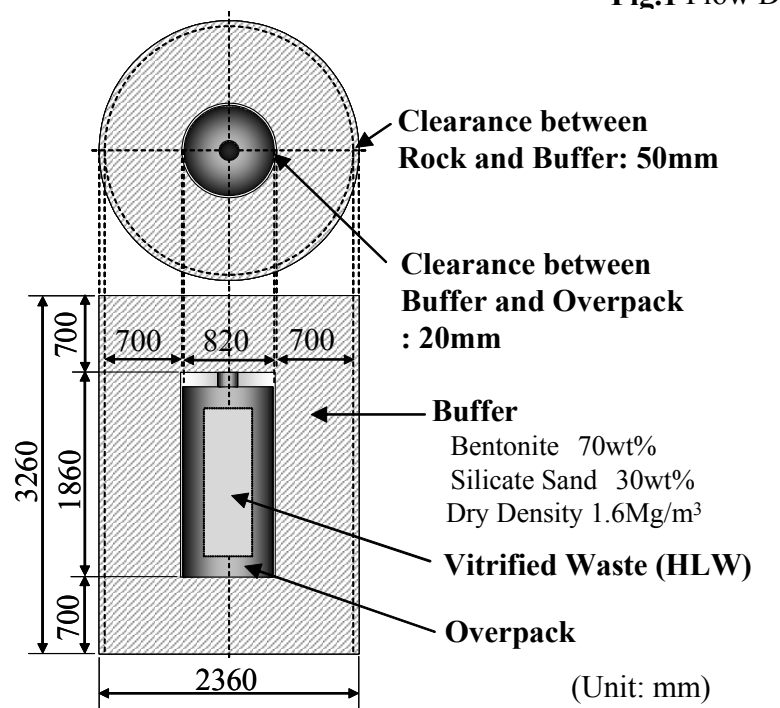

Fig.2 Buffer Speciation to be Constructed

fore required. It was tried to predict and evaluate distributions of pressure on bentonite and acceleration in bentonite with a FEM model. As a result of evaluation, the magnitude of pressure from the prediction agreed with one from the experiment. But magnitude of acceleration from prediction was ten times as large as one from the experiment and it concluded that the magnitude of acceleration was not able to be predicted accurately. As concerns acceleration defined by time and displacement, there was no consideration of propagation characteristics in the analytical model (bentonite).

In addition, this study also tried to compare the experimental results regarding acceleration with the one from analysis in use of acceleration damping ratio according to distance in bentonite. More specifically, laboratory tests of acceleration damping characteristics were conducted to learn about the relationship between buffer material specifications/compaction conditions and acceleration damping characteristics. Based on the results, the damping constant reflected in the analytical model was examined. In addition, by comparing the calculated values from the analysis (which takes accel- eration damping into consideration) with the data obtained from full-scale compaction experiments, the applicability of the analytical model for the evaluation of compaction impact effect was reviewed. This article describes the results of the above experiments and analysis.

\section{CONDITIONS FOR THE STUDY}

\section{(1) Procedures}

Figure 1 shows the flow diagram of the study. The study includes a) understanding the acceleration damping characteristics of buffer material, b) setting a damping constant (reflected in the analysis model) and c) comparing the analytical results with measured data to check the validity of the analysis model.

\section{(2) Specifications of buffer material assumed in the study}

In this study, the specifications of the buffer material to be used were based on example specifications from the "Second Progress Report on Research and Development for the Geological Disposal of HLW in Japan" (Japan Nuclear Cycle Development Institute $)^{7)}$. The specifications are shown in Fig.2. Although the required dry density for the buffer material is $1.6 \mathrm{Mg} / \mathrm{m}^{3}$, the studies of the buffer material assumed that compaction could be in the range 1.6 to $1.8 \mathrm{Mg} / \mathrm{m}^{3}$ dry density.

\section{(3) Construction of the buffer material}

The construction procedure for the buffer material in this study is shown in Fig.3. The procedure is based on a conceptual design of an operation system for engineered barrier construction ${ }^{8)}$ which was conducted separately. The compaction system is based on dynamic compaction by free weight drops.

\section{(4) Specifications of materials}

Of the possible materials for the buffer, so- 
dium-type bentonite is considered as the most favorable candidate, with its high swelling capacity and self-sealing ability from damage such as fracturing. In this study, bentonite produced at Tsukinuno in Yamagata prefecture, mixed with silicate sand composite as an aggregate, was used. The specifications and grain size cumulative curve of the material used in the experiments are shown in Table 1 and Fig.4.

\section{(5) Determination of compaction energy}

Bentonite-based buffer material becomes much stronger, compared with soil in general, because the particles bind through compaction ${ }^{3)}$. Accordingly the maximum dry density achieved by compaction is affected by the compaction energy ("striking energy") per blow. Thus, the determination of striking energy is very important in the study of compaction technique. Empirical formulae exist for determining the relationship between striking energy and the maximum dry density achieved by compaction. These formulae are shown as Equations (1) and (2), for laboratory tests and a full-scale experiment respectively, depending on the scale of compaction ${ }^{2)}$. Materials with the specifications shown in Table 1 are used in both equations, which assumed unsaturated conditions.

$$
\begin{aligned}
& \rho_{\text {dupr }}=0.161 \ln E_{\text {imp }}+2.126 \\
& \rho_{\text {dupr }}=0.231 \ln E_{\text {imp }}+2.066
\end{aligned}
$$

where,

$$
\begin{aligned}
\rho_{\text {dupr }} & : \text { Maximum dry density obtained by the } \\
& \text { compaction }\left(\mathrm{Mg} / \mathrm{m}^{3}\right) \\
E_{\text {imp }} & : \text { Striking energy }(\mathrm{Ec})
\end{aligned}
$$

In this study, the striking energy was determined by either Equation (1) or Equation (2), depending on the scale of compaction to be studied. Adjustment of the striking energy in the experiment was made by

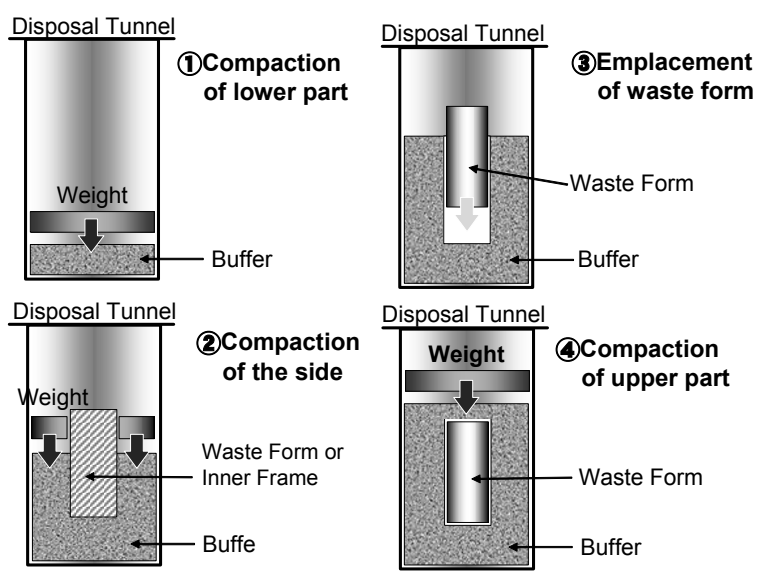

Fig.3 Construction Procedure of In-situ Compaction of Buffer material shifting the dropping height of the weight. The relationship between striking energy, dropping height and the weight mass are shown in Equation (3).

$$
E_{\text {imp }}=\frac{W_{\mathrm{R}} \cdot H \cdot N_{\mathrm{B}} \cdot N_{\mathrm{L}}}{0.0551 \mathrm{~V}}=\frac{m_{\mathrm{f}} \cdot H}{5.625 \mathrm{~V}}
$$

where,

$E_{\text {imp }}:$ Striking energy $(\mathrm{Ec})$

$W_{\mathrm{R}} \quad$ :Weight of rammer(kN)

$H \quad$ :Falling height $(\mathrm{cm})$

$N_{\mathrm{B}} \quad$ :Number of strikes $\left(N_{\mathrm{B}}=1\right.$ when calculating $\left.E_{\text {imp }}\right)$

$N_{\mathrm{L}} \quad$ :Number of layers of compaction $\left(N_{\mathrm{L}}=1\right.$ when calculating $\left.E_{\text {imp }}\right)$

$m_{\mathrm{f}} \quad$ :Mass of Weight $(\mathrm{kg})$

$V \quad$ :Volume of material $\left(\mathrm{cm}^{3}\right)$

\section{BUFFER COMPACTION EXPERIMENT AND ACQUISITION OF ACCELERATION DAMPING RATIO}

\section{(1) Objectives of the study}

When the influence of compaction impact on rock and waste form is being evaluated, one of the characteristics of buffer material to be considered is the acceleration damping characteristic. Data on the acceleration damping characteristic of buffer mate-

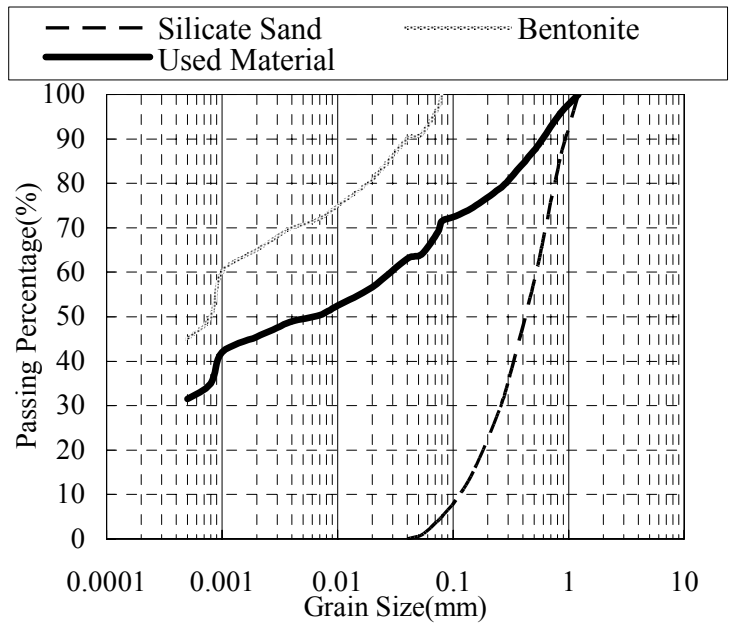

Fig.4 Grain Size Cumulative Curve

Table 1 Specification of Material Used in the Experiment

\begin{tabular}{|c|c|}
\hline Items & Specification \\
\hline Bentonite & Sodium-type Bentonite \\
\hline Silicate Sand & $\begin{array}{c}\text { Mixture of No, 3, 4, 5, 6, 7 Sand } \\
\text { (Mixed Evenly by Dry Weight) }\end{array}$ \\
\hline $\begin{array}{c}\text { Sand Mixing } \\
\text { Ratio }\end{array}$ & $30 \%$ ( By Dry Weight) \\
\hline Water Content & $15 \%$ \\
\hline Curing Period & $\begin{array}{c}24 \mathrm{hr} \text { or More after Moisture Control } \\
\text { and Mixing of Material }\end{array}$ \\
\hline
\end{tabular}


rial was obtained from experiments. Based on these data, the relative tendency of specifications/ conditions of the buffer material (composition, water content and dry density), striking energy and impact damping characteristics were analyzed.

\section{(2) Apparatus}

The apparatus used in this experiment is shown in Fig.5. It consists of a mold with an inside diameter of $300 \mathrm{~mm}$ and a steel weight of $99.7 \mathrm{~kg}$ in mass. The material inside the mold is compacted by the impact of the falling weight. Three accelerometers (A1 to A3) were installed in the vertical direction inside the buffer material and a pressure gauge (P1) and an accelerometer (A4) were installed on the base plate. A bentonite block, statically compressed to a $300 \mathrm{~mm}$ diameter and a $100 \mathrm{~mm}$ thickness, was prepared and installed in the mold, with an accelerometer mounted on the block. The pressure gauge and the accelerometer were connected to a personal computer through an amplifier and the output from the sensors was continuously recorded with a $10 \mathrm{kHz}$ sampling frequency. Because the accelerometer's maximum frequency response is $\mathrm{DC} 7 \mathrm{kHz}$, it is sufficient to record output from accelerometers with a $10 \mathrm{kHz}$ sampling frequency.

\section{(3) Experiment conditions}

For the purpose of the experiment to study the relationship between buffer material specifications / striking energy and acceleration damping characteristics, silicate sand mixing ratio, water content and dry density were defined as parameters for the buffer

Table 2 Specifications of the Sample Materials

\begin{tabular}{|c|c|c|c|}
\hline Sample ID & $\begin{array}{c}\text { Sand Mixing } \\
\text { Ratio } \\
R \mathrm{~s}(\%)\end{array}$ & $\begin{array}{c}\text { Water } \\
\text { Content } \\
w(\%)\end{array}$ & $\begin{array}{c}\text { Initial Dry } \\
\text { Density } \\
\rho_{\mathrm{d} 0}\left(\mathrm{Mg} / \mathrm{m}^{3}\right)\end{array}$ \\
\hline $\mathrm{S}-1$ & 30 & 15 & 1.50 \\
\hline $\mathrm{S}-2$ & 30 & $\mathbf{1 8}$ & 1.50 \\
\hline $\mathrm{S}-3$ & $\mathbf{5 0}$ & 15 & 1.50 \\
\hline
\end{tabular}

material specifications, while striking energy was defined as a parameter for the compaction method.

The specifications of the sample materials are listed in Table 2. The reference material is represented as $\mathrm{S}-1$ and water content and silicate sand mixing ratio are varied in S-2 and S-3, respectively. Dry density was set low in the early stage of the experiment; the dry density was then gradually increased as the experiment was repeated several times to obtain data for the relationship between dry density and damping characteristics.

The striking energy required to achieve a dry density of 1.6 to $1.8 \mathrm{Mg} / \mathrm{m}^{3}$ was calculated using Equation (1). The required striking energy was 0.04 to $0.14 \mathrm{Ec}$ and the falling height of the weight according to the striking energy was calculated using Equation (3). Based on the result, the falling heights of the weight were determined to be in the range 20 to 50 $\mathrm{cm}$.

\section{(4) Experiment procedure}

The experiment consists of 2 steps. Figure 6 shows the experiment procedure and the conditions. In Step 1 , where the objective was to identify the relationship between dry density and damping characteristics, data was collected by increasing dry density while the striking energy was maintained at a fixed level. In Step 2, where the objective was to identify the relationship between striking energy and damping characteristics, data was collected by decreasing the striking energy while maintaining the dry density at a constant level. Following the procedure, the weight was dropped on the buffer material and the data output from each sensor per drop was recorded. The lift from the buffer material was also measured for each drop and the dry density was calculated using the initial dry density and the change in the lift. The lift was measured as the distance between the upper end of the mold and the upper cover of the buffer material.

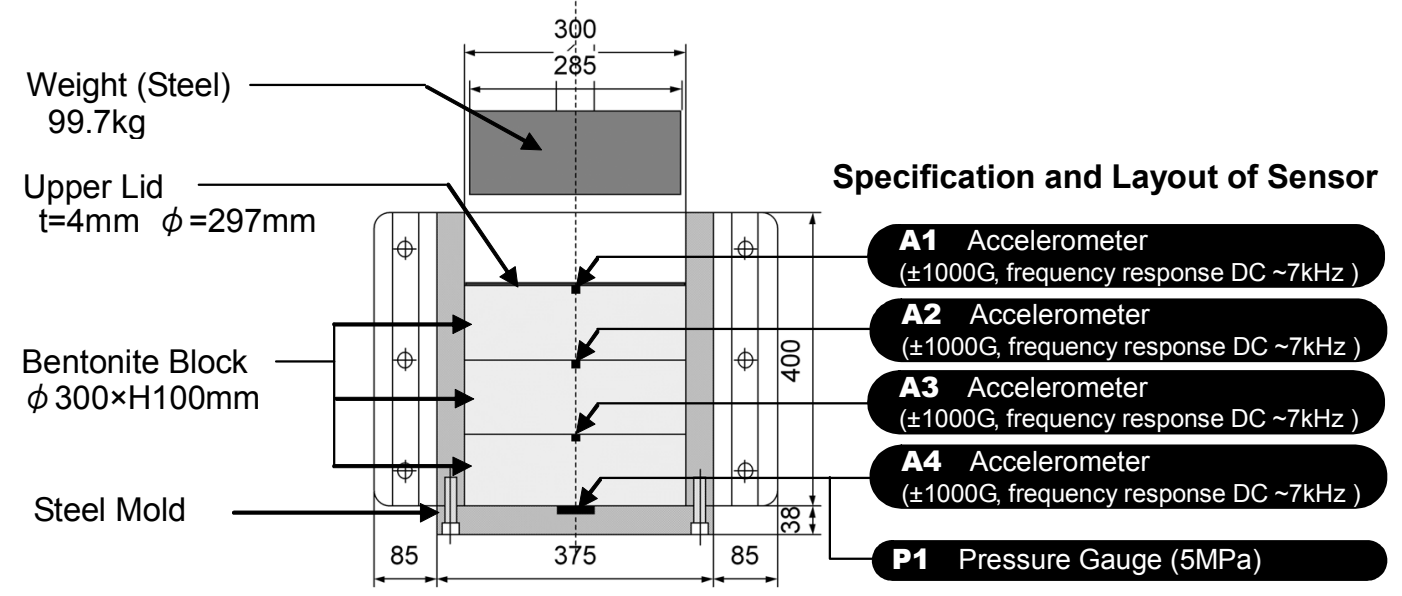

Fig.5 Acceleration Damping Test Apparatus 
All experiment conditions are listed in Table 3. Although measurements were made for every weight drop, out of space considerations the data are noted only for every 3 drops. The falling distance of the weight and the dry density values shown in Table 3 is calculated using measurements of the lift. The falling height was fixed at $30 \mathrm{~cm}$ of the lift as a set point and the striking energy thus varies slightly with the change in the lift.

\section{(5) Experiment results}

The waveforms of acceleration and pressure obtained from the experiment (S-1, 27 th strike) are shown in Figs.7 and 8. The peak height of the wave was taken as the measured value for the particular case. Figure 7 shows that 4 waveforms separate significantly and it is clear that peaks of waveforms decrease with propagation.

Figure 9 shows the relationship between dry density measured in Step 1 and the acceleration, which is the magnitude of amplitude at the initial motion of waveform, at each measuring point for the material $\mathrm{S}-1$. The accelerations measured at the upper position in the buffer material (A1) were consistent, slightly over $800 \mathrm{G}$ in all cases. This consistency was considered to indicate that the acceleration had exceeded the capacity of the accelerometer. The trend of damping with the propagation of acceleration was observed for accelerometers at the middle position (A2), the lower position (A3), and on the plate (A4), but the data was widely dispersed.

Figure 10 shows the relationship between striking energy measured in Step 2 and the acceleration at each measuring point for the material S-1. It is apparent that the acceleration increases at each point with an increase in the striking energy. Similarly, pressures measured at $\mathrm{P} 1$ are listed in order in
Figs.11 and 12. In both figures, dispersion is small and a linear relationship is represented. Evidently, the pressure tends to increase with the increase in striking energy and dry density. Due to an excessive amount of data for the limited space available, only S-1 results are shown here. However, S-2 and S-3 results also showed a similar tendency.

As concerns phenomena of damping in bentonite, there are two noteworthy. One is caused by distance between two observation points and the other is caused by the material itself. In evaluation of this study, we use the former, what is referred to as attenuation. The relationship between attenuation and dry density/striking energy is shown in Figs.13 and 14. The attenuation equation is defined as in Equation (4). The upper position (A1) and the mold

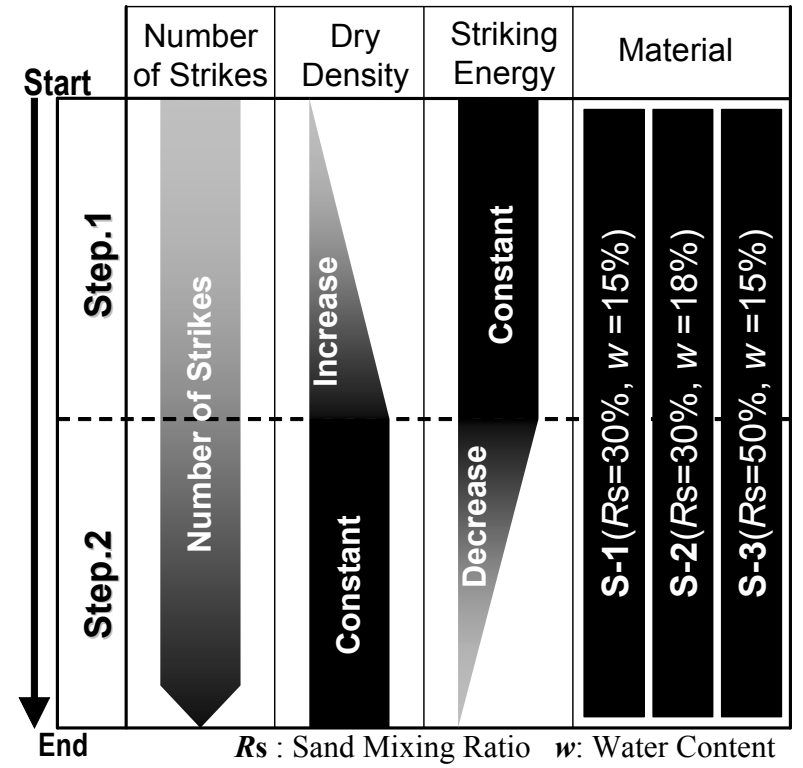

Fig.6 Acceleration Damping Test Procedure

Table 3 Experiment Conditions of Damping Characteristics

\begin{tabular}{|c|c|c|c|c|c|c|c|c|c|c|c|}
\hline \multirow[b]{2}{*}{ Step } & \multirow[b]{2}{*}{ 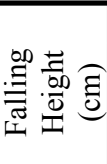 } & \multirow{2}{*}{ 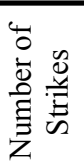 } & \multicolumn{3}{|c|}{$\mathrm{S}-1 \quad(R \mathrm{~s}=30 \%, w=15 \%)$} & \multicolumn{3}{|c|}{$\mathrm{S}-2(R \mathrm{~s}=30 \%, w=18 \%)$} & \multicolumn{3}{|c|}{$\mathrm{S}-3(R \mathrm{~S}=50 \%, w=15 \%)$} \\
\hline & & & $\begin{array}{l}\text { Buffer } \\
\text { Thickness } \\
\text { (mm) }\end{array}$ & $\begin{array}{c}\text { Dry } \\
\text { Density } \\
\left(\mathrm{Mg} / \mathrm{m}^{3}\right)\end{array}$ & $\begin{array}{l}\text { Striking } \\
\text { Energy } \\
(\mathrm{Ec})\end{array}$ & $\begin{array}{l}\text { Buffer } \\
\text { Thickness } \\
\text { (mm) }\end{array}$ & $\begin{array}{c}\text { Dry } \\
\text { Density } \\
\left(\mathrm{Mg} / \mathrm{m}^{3}\right)\end{array}$ & $\begin{array}{l}\text { Striking } \\
\text { Energy } \\
(\mathrm{Ec})\end{array}$ & $\begin{array}{l}\text { Buffer } \\
\text { Thickness } \\
\text { (mm) }\end{array}$ & $\begin{array}{c}\text { Dry } \\
\text { Density } \\
\left(\mathrm{Mg} / \mathrm{m}^{3}\right)\end{array}$ & $\begin{array}{l}\text { Striking } \\
\text { Energy } \\
(\mathrm{Ec})\end{array}$ \\
\hline \multirow{10}{*}{ Step.1 } & \multirow{10}{*}{50} & 0 & 313 & 1.438 & - & 310 & 1.452 & - & 305 & 1.475 & - \\
\hline & & 3 & 303 & 1.485 & 0.123 & 299 & 1.505 & 0.126 & 295 & 1.525 & 0.129 \\
\hline & & 6 & 300 & 1.500 & 0.125 & 295 & 1.525 & 0.129 & 294 & 1.531 & 0.129 \\
\hline & & 9 & 297 & 1.515 & 0.127 & 291 & 1.546 & 0.132 & 292 & 1.541 & 0.131 \\
\hline & & 12 & 294 & 1.531 & 0.129 & 289 & 1.557 & 0.133 & 288 & 1.563 & 0.134 \\
\hline & & 15 & 292 & 1.541 & 0.131 & 286 & 1.573 & 0.135 & 287 & 1.568 & 0.134 \\
\hline & & 18 & 291 & 1.546 & 0.132 & 284 & 1.585 & 0.137 & 285 & 1.579 & 0.136 \\
\hline & & 21 & 290 & 1.552 & 0.132 & 282 & 1.596 & 0.138 & 283 & 1.590 & 0.137 \\
\hline & & 24 & 288 & 1.563 & 0.134 & 280 & 1.607 & 0.14 & 283 & 1.590 & 0.137 \\
\hline & & 27 & 287 & 1.568 & 0.134 & 278 & 1.619 & 0.141 & 282 & 1.596 & 0.138 \\
\hline 1,2 & 50 & 30 & 285 & 1.579 & 0.136 & 277 & 1.625 & 0.142 & 282 & 1.596 & 0.138 \\
\hline \multirow{3}{*}{ Step.2 } & 40 & 33 & 285 & 1.579 & 0.110 & 276 & 1.630 & 0.116 & 281 & 1.601 & 0.112 \\
\hline & 30 & 36 & 285 & 1.579 & 0.083 & 276 & 1.630 & 0.088 & 280 & 1.607 & 0.086 \\
\hline & 20 & 39 & 285 & 1.579 & 0.057 & 276 & 1.630 & 0.061 & 280 & 1.607 & 0.059 \\
\hline
\end{tabular}




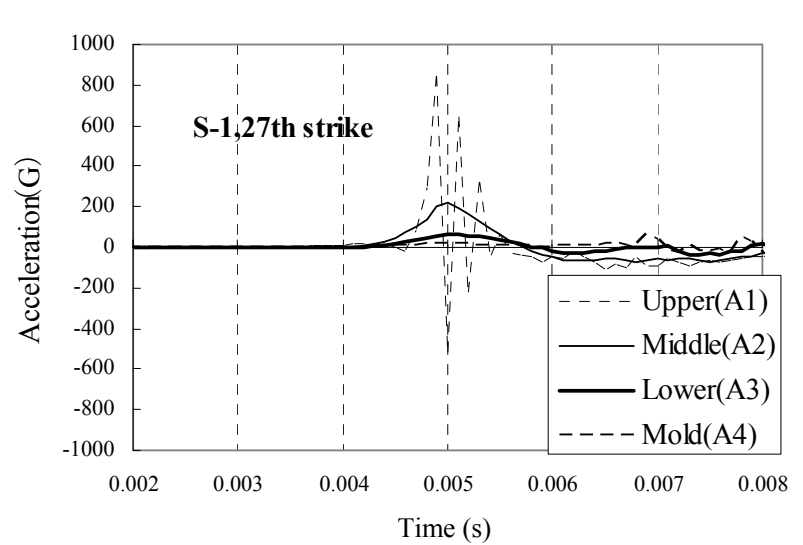

Fig.7 Sample of Waveform of Acceleration from the Experiment

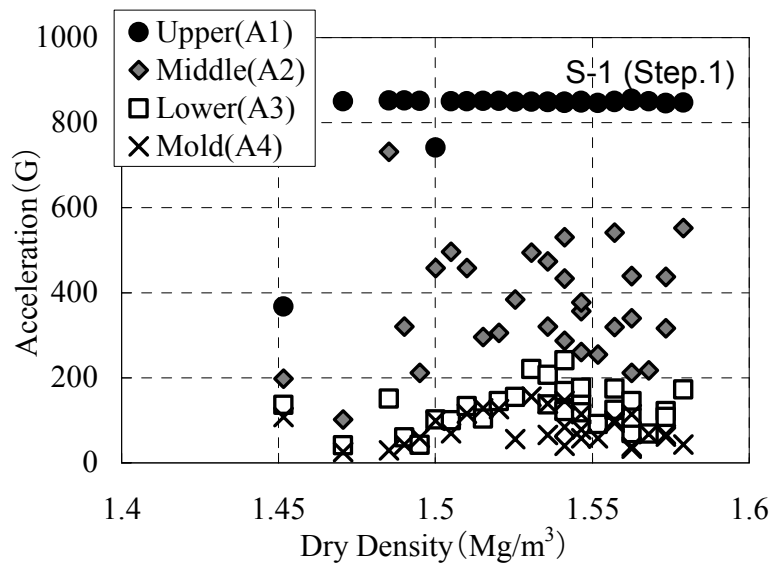

Fig.9 Relation between Dry Density and Acceleration

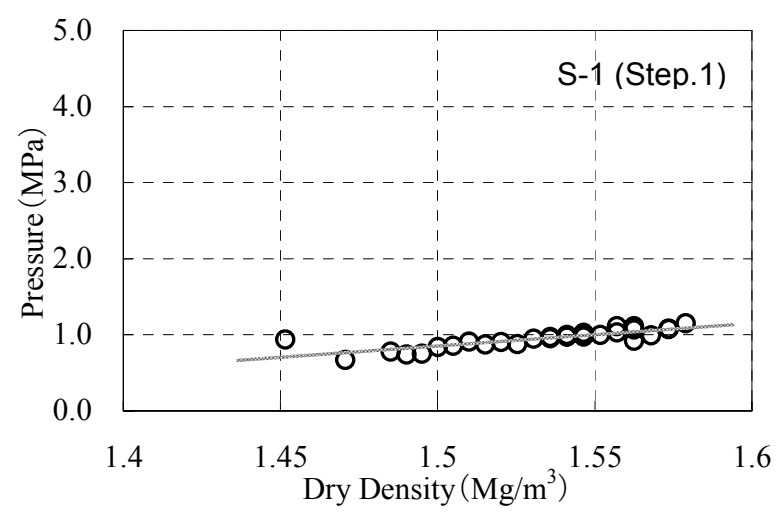

Fig.11 Relation between Dry Density and Pressure

bottom were omitted in this study because they exceeded the accelerometer's capacity and measurement errors could have a significant effect.

$$
\zeta_{\mathrm{a}}=\frac{a_{\mathrm{A} 3}}{a_{\mathrm{A} 2}}
$$

where,

$\zeta_{\text {a }}:$ Attenuation ratio

$\alpha_{\mathrm{A} 3}$ :Acceleration $(\mathrm{G})$ measured at the lower position (A3)

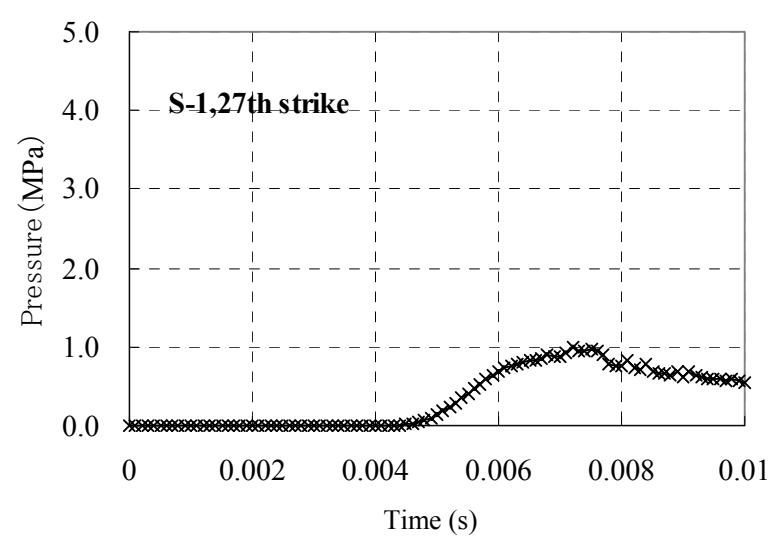

Fig.8 Sample of Waveform of Pressure from the Experiment

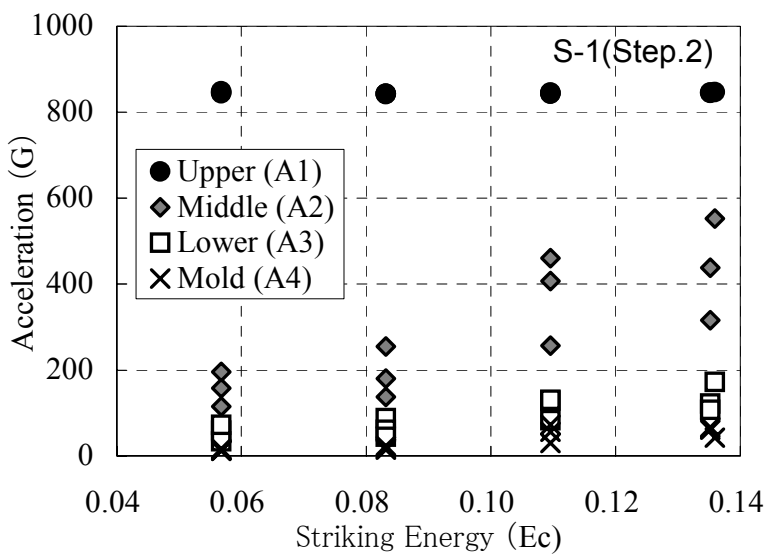

Fig.10 Relation between Striking Energy and Acceleration

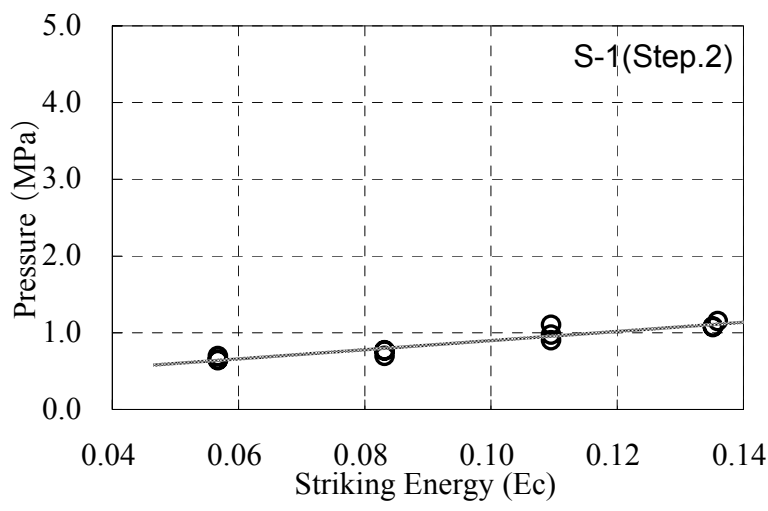

Fig.12 Relation between Striking Energy and Pressure

$\alpha_{\mathrm{A} 2}:$ Acceleration $(\mathrm{G})$ measured at the middle
position (A2)

As for the relationship between dry density and attenuation ratio, a consistent tendency cannot be observed in the region of low dry density. However, in the region of high dry density $\left(1.55 \mathrm{Mg} / \mathrm{m}^{3}\right.$ or higher), the attenuation ratio converges in the range 0.3 to 0.4 regardless of material specifications or dry density. In the relationship between striking energy and attenuation ratio, the attenuation ratio distributes in the range 0.3 to 0.4 , regardless of the degree of 


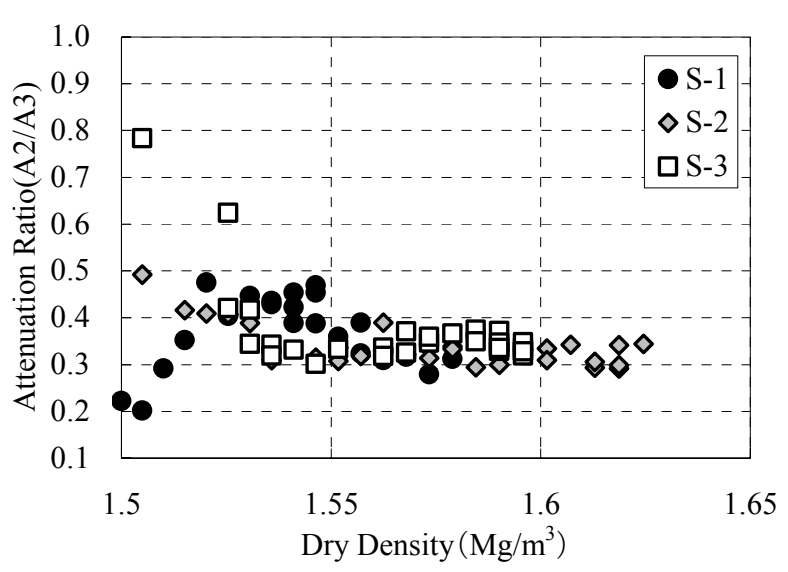

Fig.13 Relation between Dry Density and Attenuation Ratio

striking energy. In other words, in the region of 1.55 $\mathrm{Mg} / \mathrm{m}^{3}$ or higher dry density of the buffer material, the acceleration damping ratio ranges consistently from 0.3 to 0.4 , as long as the dry density, water content, silicate sand mixing ratio and striking energy are given as parameters with the same range as in this experiment. Evidently, the acceleration damping ratio depends very little on the material specifications or on the striking energy.

Meanwhile, although no specific tendency can be recognized in the relationship between dry density and the attenuation ratio in the region of low dry density $\left(1.55 \mathrm{Mg} / \mathrm{m}^{3}\right.$ or less), some continuity can observed in connection with each change, indicating that it is not due to a dispersion of the measurements. The sensor and the buffer material, or the bentonite blocks, were not evenly in contact at the beginning of the experiment and this may be the reason why accurate values could not be measured until they began to align with the increase in density.

In this experiment, the attenuation ratio was consistent in the range of 0.3 to 0.4 , regardless of the material used or compaction conditions. However, these values depend on the test conditions and, when reflecting the actual compaction impact effect analysis, a damping parameter for the analysis model thus needs to be provided. In the next section, the damping constant is discussed using an inverse analysis of the experiment.

\section{SETTING THE DAMPING CONSTANT}

\section{(1) Analysis code}

The analysis program used in this study was ABAQUS version 6.2 (ABAQUS, Inc). Since the inside of the disposal pit, where the waste form and buffer material are emplaced, can be represented by axial symmetry, an analytical model was developed using an axial symmetry model by 2 -dimensional

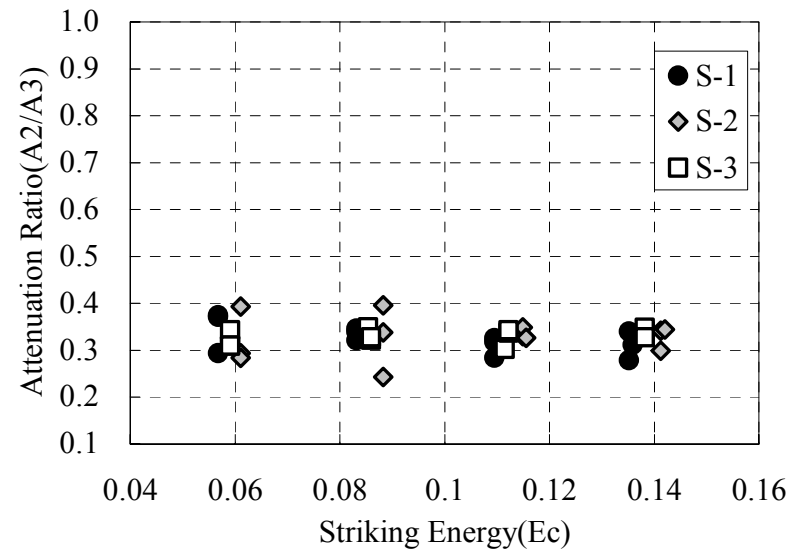

Fig.14 Relation between Striking Energy and Attenuation Ratio

FEM analysis.

\section{(2) Evaluation method for acceleration damping characteristics of buffer material}

The Rayleigh damping theory was introduced to evaluate the damping of the acceleration propagated through the buffer material in the compaction impact effect analysis. Rayleigh damping consists of a term which attenuates depending on the mass and another term which is in proportion to rigidity. This is described in the equation below. In Equation (5), there are two damping constants, $\alpha_{\mathrm{R}}$ and $\beta_{\mathrm{R}}$. In existing studies, it is considered acceptable if mass damping is ignored in vibration with a high frequency larger than $3 \mathrm{~Hz}$. In Figure 7, as frequency of acceleration in this model is high, in construction of buffer material such as this experiment, it is appropriate to take rigidity damping into consideration. Therefore, in this study, $\alpha_{\mathrm{R}}$ was fixed at 0 and the value of $\beta_{\mathrm{R}}$ was changed, and the results of analysis were evaluated.

$$
[C]=\alpha_{\mathrm{R}}[M]+\beta_{\mathrm{R}}[K]
$$

where,

$[C]$ :Damping matrix

$[M]$ :Mass matrix

$[K]$ :Rigidity matrix

$\alpha_{\mathrm{R}}$ :Mass dependent damping constant $\left(\mathrm{s}^{-1}\right)$

$\beta_{\mathrm{R}}$ : Rigidity dependent damping constant (s)

\section{(3) Damping constant}

\section{a) Analysis conditions}

An inverse analysis, with the damping constant as a parameter, was performed to identify the damping constant of the buffer material by comparing acceleration and pressure obtained in the analysis using the measured data.

The situation subjected to the inverse analysis was that where a weight was dropped on the buffer 
material S-1, which was compacted to the dry density of $1.6 \mathrm{Mg} / \mathrm{m}^{3}$, from a height of $50 \mathrm{~cm}$. The analysis model used in the study and the material constant used in the analysis are shown in Fig.15 and Table 4. Also, the damping constant for each analysis case is summarized in Table 5.

\section{b) Result of the analysis and setting the damping constant}

The waveforms of acceleration and earth pressure are shown in Figs.16 and 17. Table6 shows all the analysis results obtained from the peak height sampled from the waves.

In Figure 16, waveforms of acceleration obtained from analysis differ significantly from the one obtained from a full-scale compaction experiment. In this study, as the main purpose is to compare the peak of acceleration waveform obtained from analysis with the one obtained from a full-scale compaction experiment, it is not necessary to match waveforms of acceleration obtained from analysis with the ones obtained from a full-scale compaction experiment.

In Table 6, the acceleration damping ratio $\zeta_{\mathrm{a}}$, the acceleration of each measuring point and the measured value of earth pressure in the range of middle (A2) to bottom (A3) lifts were compared. Case 4

Table 4 Properties of the Materials

\begin{tabular}{|c|c|c|c|}
\hline Materials & $\begin{array}{c}\text { Weight } \\
\left(\mathrm{Mg} / \mathrm{m}^{3}\right)\end{array}$ & $\begin{array}{c}\text { Elastic } \\
\text { Modulus } \\
(\mathrm{MPa})\end{array}$ & $\begin{array}{c}\text { Poisson's } \\
\text { Ratio }\end{array}$ \\
\hline Bentonite & 1.6 & $1.242 \times 10^{2}$ & 0.4 \\
\hline Concrete & 2.3 & $2.5 \times 10^{4}$ & 0.2 \\
\hline Weight & 7.8 & $2.0 \times 10^{5}$ & 0.3 \\
\hline Mold & 7.8 & $2.0 \times 10^{5}$ & 0.3 \\
\hline
\end{tabular}

Table 5 Range of Damping Constants

\begin{tabular}{|c|c|c|}
\hline \multirow{2}{*}{ Case } & \multicolumn{2}{|c|}{ Rayleigh Damping Constant } \\
\cline { 2 - 3 } & $\alpha_{\mathrm{R}}\left(\mathrm{s}^{-1}\right)$ & $\beta_{\mathrm{R}}(\mathrm{s})$ \\
\hline 1 & 0.0 & 0.0001 \\
\hline 2 & 0.0 & 0.0005 \\
\hline 3 & 0.0 & 0.001 \\
\hline 4 & 0.0 & 0.005 \\
\hline 5 & 0.0 & 0.01 \\
\hline
\end{tabular}

shows a relatively high consistency for all parameters. As a result, Rayleigh damping constants for the buffer material were fixed as $\beta_{\mathrm{R}}=0.005\left(\alpha_{\mathrm{R}}=0\right)$.

\section{VALIDATION THE ANALYSIS CODE AGAINST FULL-SCALE COMPACTION EXPERIMENT}

\section{(1) General}

In this section, the analysis model for compaction impact effect using the damping constant as set in the previous section was validated by comparing the model with the measured values for acceleration and pressure obtained from a full-scale compaction experiment which simulates actual construction of the buffer material.

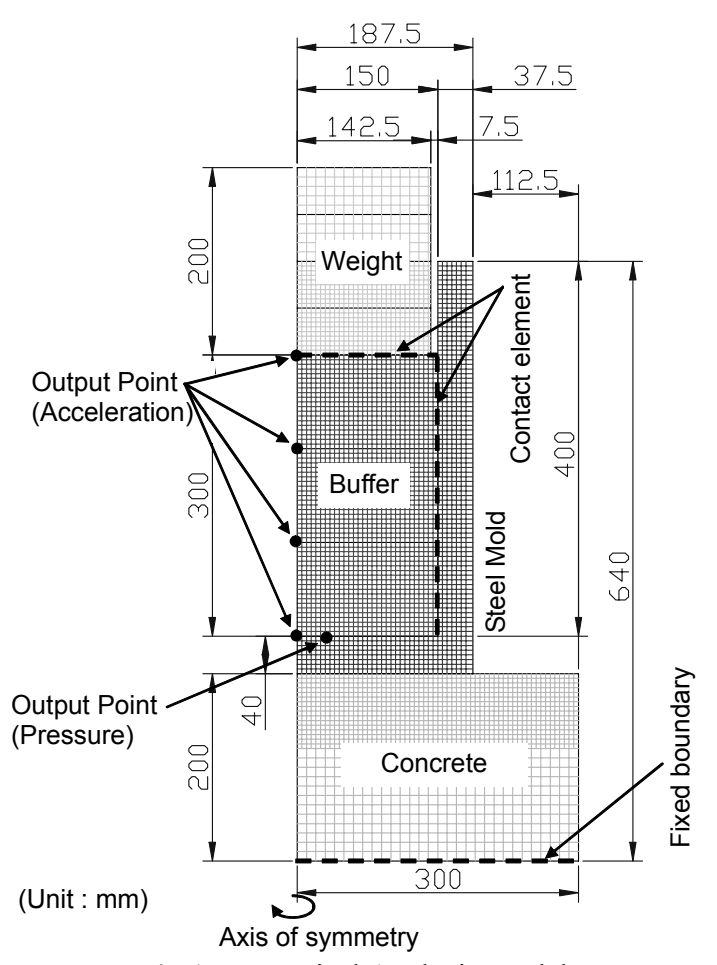

Fig.15 Numerical Analysis Model

Table 6 Acceleration Damping Ratios Obtained from Analyses and Measurements

\begin{tabular}{|c|c|c|c|c|c|c|c|c|}
\hline \multirow{2}{*}{\multicolumn{2}{|c|}{ Item }} & \multirow{2}{*}{ Unit } & \multicolumn{5}{|c|}{ Analysis } & \multirow{2}{*}{$\begin{array}{c}\text { Measurement } \\
\text { Value }\end{array}$} \\
\hline & & & Case1 & Case2 & Case 3 & Case4 & Case5 & \\
\hline \multirow{2}{*}{$\begin{array}{l}\text { Rayleigh } \\
\text { Damping } \\
\text { Constant } \\
\end{array}$} & $\alpha_{\mathrm{R}}$ & $\mathrm{s}^{-1}$ & 0 & 0 & 0 & $\mathbf{0}$ & 0 & - \\
\hline & $\beta_{\mathrm{R}}$ & $\mathrm{s}$ & 0.0001 & 0.0005 & 0.001 & 0.005 & 0.01 & - \\
\hline \multirow{5}{*}{ Acceleration } & Buffer-Upper point (A1) & $\mathrm{G}$ & 1527 & 1610 & 1560 & 1204 & 963 & $800 \sim$ \\
\hline & Buffer-Middle point (A2) & $\mathrm{G}$ & 657 & 669 & 763 & 750 & 611 & $200 \sim 550$ \\
\hline & Buffer-Lower point (A3) & $\mathrm{G}$ & 572 & 260 & 294 & 311 & 251 & $60 \sim 250$ \\
\hline & Mold (A4) & $\mathrm{G}$ & 12 & 2 & 3 & 3 & 1 & $30 \sim 160$ \\
\hline & $\zeta_{\mathrm{a}}$ & - & 0.87 & 0.39 & 0.39 & 0.41 & 0.41 & $0.3 \sim 0.4$ \\
\hline Pressure & Mold (P1) & $\mathrm{MPa}$ & 3.01 & 2.40 & 2.00 & 0.75 & 0.41 & $0.8 \sim 1.1$ \\
\hline Displacement & Buffer Surface & $\mathrm{mm}$ & 4.07 & 3.54 & 3.06 & 1.62 & 1.08 & - \\
\hline
\end{tabular}




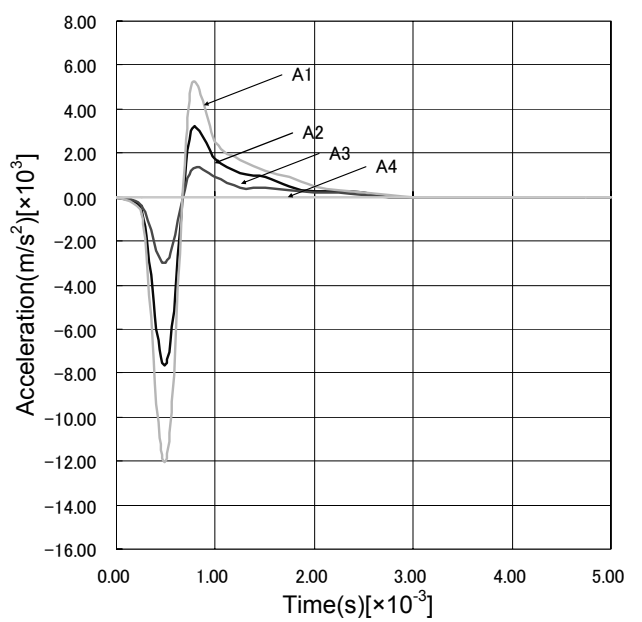

Fig.16 Waveforms of Acceleration Obtained from Analysis

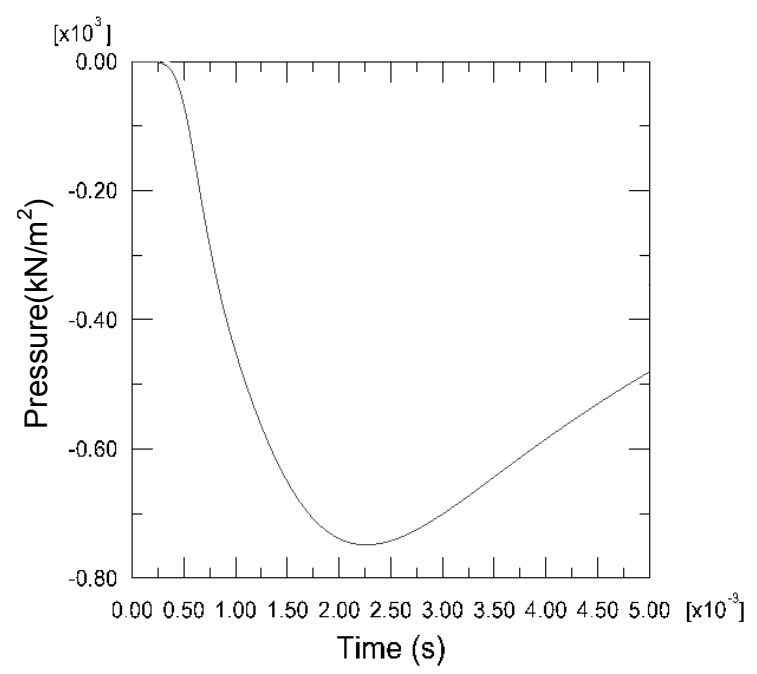

Fig.17 Waveforms of Earth Pressure Obtained from Analysis

\section{(2) Measured data for comparison}

The measured data for comparison was obtained from the pressure gauge and the accelerometer which had been installed for the buffer material mock construction experiment ${ }^{10}$ which was conducted separately. The mock construction experiment was a full-scale compaction experiment, simulating construction of the buffer material using the in-situ compaction technique. The compaction was carried out under approximately the same conditions as the actual buffer material compaction.

The experiment system is shown in Fig.18, which simulates the compaction as in "2.Compaction of the Side" in Fig.3. A simulated waste form (inner frame) was installed at the center of the disposal pit in order to establish a waste form insertion pit. Compaction was performed with a device with weights (fan-shaped, central angle of $20^{\circ}$ ) attached on both sides symmetrically. The compaction device has a weight of $2,100 \mathrm{~kg}$, including coupling parts, and an area of contact with the buffer material (pressure
Table 7 Specification of the Buffer

\begin{tabular}{|c|c|c|c|c|}
\hline Layers & $\begin{array}{c}\text { Thick- } \\
\text { ness } \\
(\mathrm{mm})\end{array}$ & $\begin{array}{c}\text { Dry } \\
\text { Density } \\
\left(\mathrm{Mg} / \mathrm{m}^{3}\right)\end{array}$ & $\begin{array}{c}\text { Sand } \\
\text { Mixture } \\
\text { Ration }(\%)\end{array}$ & $\begin{array}{c}\text { Water } \\
\text { Content } \\
(\%)\end{array}$ \\
\hline $3^{\text {rd }}$ Layer & 100 & 1.6 & 30 & 15 \\
\hline $2^{\text {nd }}$ Layer & 100 & 1.9 & 30 & 15 \\
\hline $1^{\text {st }}$ Layer & 100 & 1.6 & 30 & 15 \\
\hline
\end{tabular}

Table 8 Analysis Condition

\begin{tabular}{|c|c|c|c|c|}
\hline \multirow[b]{2}{*}{ Case } & \multicolumn{2}{|c|}{ Buffer } & \multirow[b]{2}{*}{$\begin{array}{c}\text { Striking } \\
\text { Energy }\end{array}$} & \multirow[b]{2}{*}{$\begin{array}{r}\text { Damping } \\
\text { Constant } \\
\left(\alpha_{\mathrm{R}} / \beta_{\mathrm{R}}\right)\end{array}$} \\
\hline & $\begin{array}{c}\text { Thickness } \\
\text { (mm) }\end{array}$ & $\begin{array}{c}\text { Dry } \\
\text { Density } \\
\left(\mathrm{Mg} / \mathrm{m}^{3}\right)\end{array}$ & & \\
\hline ST-1nd & 100 & 1.6 & $0.3 \mathrm{Ec}$ & $0.0 / 0.0$ \\
\hline ST-1d & 100 & 1.6 & $0.3 \mathrm{Ec}$ & $0.0 / 0.005$ \\
\hline ST-3nd & 300 & 1.6 & $0.3 \mathrm{Ec}$ & $0.0 / 0.0$ \\
\hline ST-3d & 300 & 1.6 & $0.3 \mathrm{Ec}$ & $0.0 / 0.005$ \\
\hline
\end{tabular}

Table 9 Properties of Materials

\begin{tabular}{|c|c|c|c|}
\hline \multirow{2}{*}{ Materials } & $\begin{array}{c}\text { Weight } \\
\left(\mathrm{Mg} / \mathrm{m}^{3}\right)\end{array}$ & $\begin{array}{c}\text { Elastic } \\
\text { Modulus } \\
(\mathrm{MPa})\end{array}$ & $\begin{array}{c}\text { Poisson's } \\
\text { Ratio }\end{array}$ \\
\hline Bentonite & 1.6 & $1.242 \times 10^{2}$ & 0.4 \\
\cline { 2 - 4 } & 1.9 & $1.392 \times 10^{2}$ & 0.4 \\
\hline Concrete $^{*}$ & 2.3 & $3.23 \times 10^{4}$ & 0.2 \\
\hline Weight & 18.2 & $2.0 \times 10^{5}$ & 0.3 \\
\hline Inner Frame & 7.8 & $2.0 \times 10^{5}$ & 0.3 \\
\hline
\end{tabular}

※ Strain Rate Dependency is Taken into Consideration for the Properties of Concrete

receiver) of $3,800 \mathrm{~cm}^{2}\left(1,900 \mathrm{~cm}^{2} \times 2\right)$, and is capable of rotating in the range of $160^{\circ}$. The weight is lifted by a wire and then freely dropped from a fixed height for compaction. Sensors were arranged as shown on the right side of Fig.18, while pressure gauges and accelerometers are mounted at the bottom and the side of the concrete pit. For the measurement of pressure and acceleration caused by compaction impact, the weight was fixed so that the sensors were arranged on the central axis of the weight and it was dropped on the buffer material from a fixed height. The outputs from each sensor were recorded on a personal computer. The method of obtaining and processing data was basically the same as for the acceleration damping characteristics experiment mentioned earlier.

The material used in the experiment was S-1 in Table 2. Two cases were tested in terms of compaction lift: $100 \mathrm{~mm} \times 1$ lift and $100 \mathrm{~mm} \times 3$ lifts. Specifications for each lift are shown in Table 7. The striking energy produced by compaction and the dropping height were set as $0.3 \mathrm{Ec}$ and $30 \mathrm{~cm}$ respectively. Applying Equation (2), the magnitude of the striking energy is capable of generating compaction up to approximately $1.8 \mathrm{Mg} / \mathrm{m}^{3}$ dry density.

\section{(3) Analysis model}

The analysis model, the conditions for the analysis and the properties of each material are shown in 
Fig.19, Tables 8 and 9, respectively. The axial symmetry model representing the system in Fig.18 is shown in Fig.19.

\section{a) FEM model}

Concrete pit, buffer material, weight and inner frame were made into a FEM model with two dimensional axial symmetric elements. Each element was treated as plastic materials and properties of materials shown as Table 9. As concerns buffer material, we take damping of acceleration into consideration and use values, $\alpha_{\mathrm{R}}=0, \beta_{\mathrm{R}}=0.005$. With regard to the elastic modulus, because the relationship between stress and strain in the loading process differs from the one in unloading and because residual strain occurs in buffer materials, it is necessary to give a constitutive equation of non-liner elasto-plastic behavior. But in this study, the main purpose being evaluation of pressure and acceleration occurring in concrete through the medium of buffer material, it was decided to treat plastic material in the use of static elastic modulus obtained from experiments. On the other hand, as concerns concrete, velocity-dependency was taken into consideration with the elastic modulus. Concerning steel, it is not necessary to evaluate elasticity and destruction of steel, so the static elastic modulus was used ${ }^{11)}$.

\section{b) Loading condition}

As the shape of actual weight is a fan whose center angle is 20 degrees, it is impossible to model actual weight in two-dimensional axial symmetric model. In this analysis, the shape of the weight was assumed as a donut ring that is possible to press the full face of buffer material simultaneously. As the weight consists of two fans and connecter, unit weight of the weight was calculated in consideration of connecter weight, but the shape of connecter was ignored in modeling. Unit weight and dimension of the weight in analytical model are as follows;

Outer diameter $(D): 1124 \mathrm{~mm}$

Inner diameter $(d): 450 \mathrm{~mm}$

Height $(h): 300 \mathrm{~mm}$

Center angle $(\theta): 20$ degree

Volume of a weight in analysis $(V)$ :

$$
V=\frac{(D-d)^{2} \times h \times \theta}{360^{\circ}}=1.0 \mathrm{~m}^{3}
$$

Actual weight of a weight $(W): 2.1 \mathrm{Mg}$

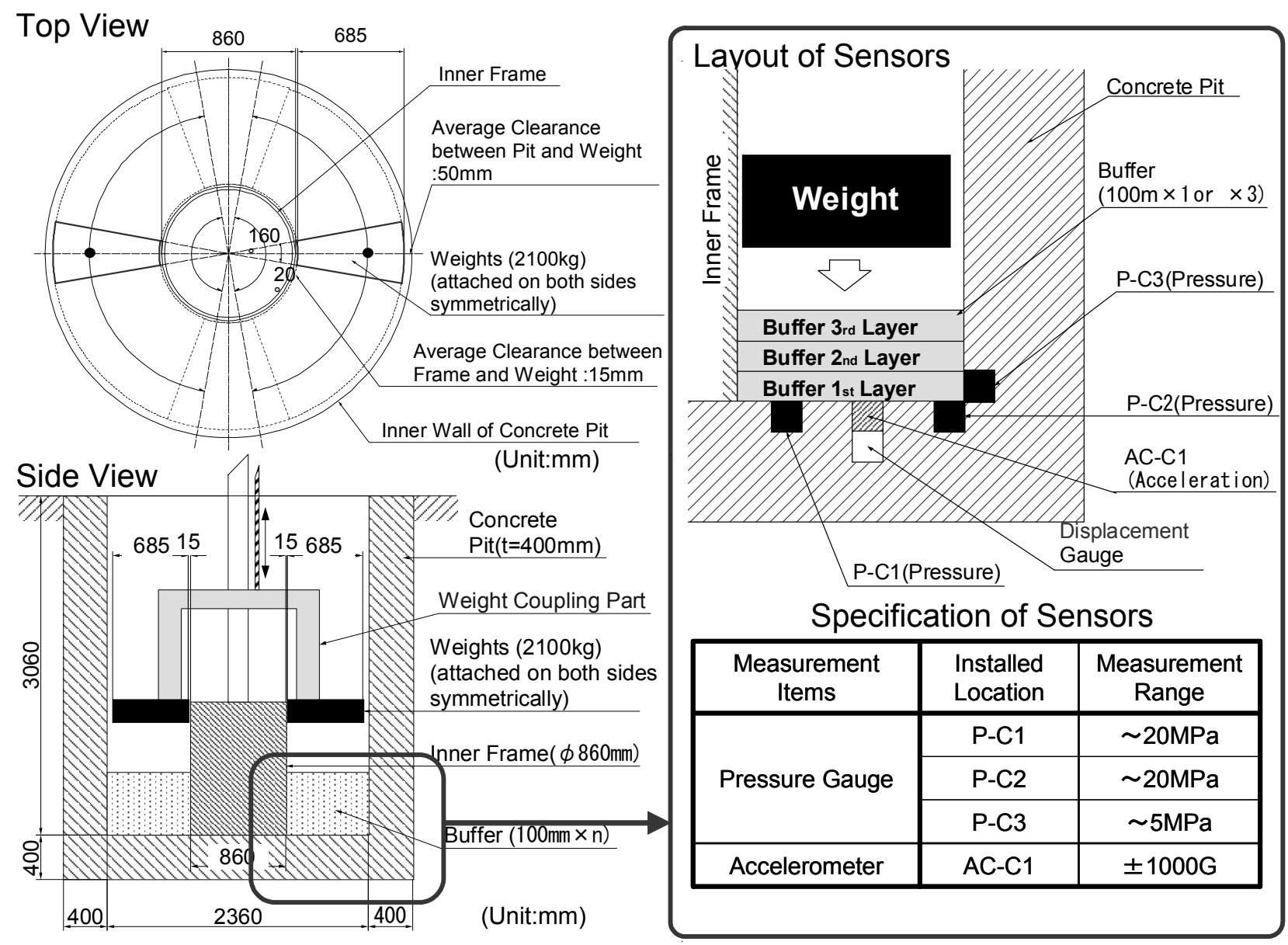

Fig.18 Outline of the Full-Scale Compaction Experiment 
Therefore,

Unit weight of a weight $(\rho)$ :

$$
\rho=\frac{W \times 360^{\circ}}{\theta \times V}=18.9 \mathrm{Mg} / \mathrm{m}^{3}
$$

Height of drop $\left(h_{\mathrm{R}}\right)$, height of the weight $(h)$ and velocity of the weight at the time when the weight contacts the buffer material $(v)$ are calculated from the following equation.

Thickness of compaction layer $\left(t_{\mathrm{b}}\right): 100 \mathrm{~mm}$

$$
\begin{aligned}
& \alpha \mathrm{Ec}=\frac{h_{\mathrm{R}} \times \rho \div 1000 \times h}{t_{\mathrm{b}} \times 5.625} \operatorname{Ec}(\alpha=0.1,0.3) \\
& \therefore h=\frac{\alpha \times t_{\mathrm{b}} \times 5.625}{h_{\mathrm{R}} \times \rho \div 1000} \\
& v=\sqrt{2 g h}
\end{aligned}
$$

Furthermore, because the results of analysis were compared with ones of the full-scale experiment about behavior at the time of Weight dropping (compaction), the unit weight of other materials except for Weight was ignored in analysis.

\section{c) Contact condition}

Behavior between Weight and buffer is thought to be influenced by transmission of each compression at the time of Weight dropping. So in this study, transmission of normal stress about each compression was considered, but transmission of normal stress from tensile and shear stress from friction was not considered. Additionally, connections between buffer material and inner frame, concrete and buffer material, were treated as rigid connections.

\section{d) Boundary condition}

In a full-scale compaction experiment, the concrete pit is buried in the well compacted soil layer, so the boundary condition of outer bottom of concrete pit is non-displacement condition. Also, the boundary condition at the side wall is free surface boundary condition because that surrounding soil is not very hard.

\section{e) Solving condition}

Dynamic analysis was completed and the Hilber-Hughes-Taylor method, which was provided by ABAQUS ver 6.2 (ABAQUS, Inc.), was used as a solving function. As concerns time increments in analysis, because sampling rate is $10 \mathrm{kHz}$, in order to cover a peak of response waveform in analysis, it was analyzed at $100 \mathrm{kHz}$. This is one tenth as large as the actual sampling rate. The duration time of analysis is 0.01 seconds.

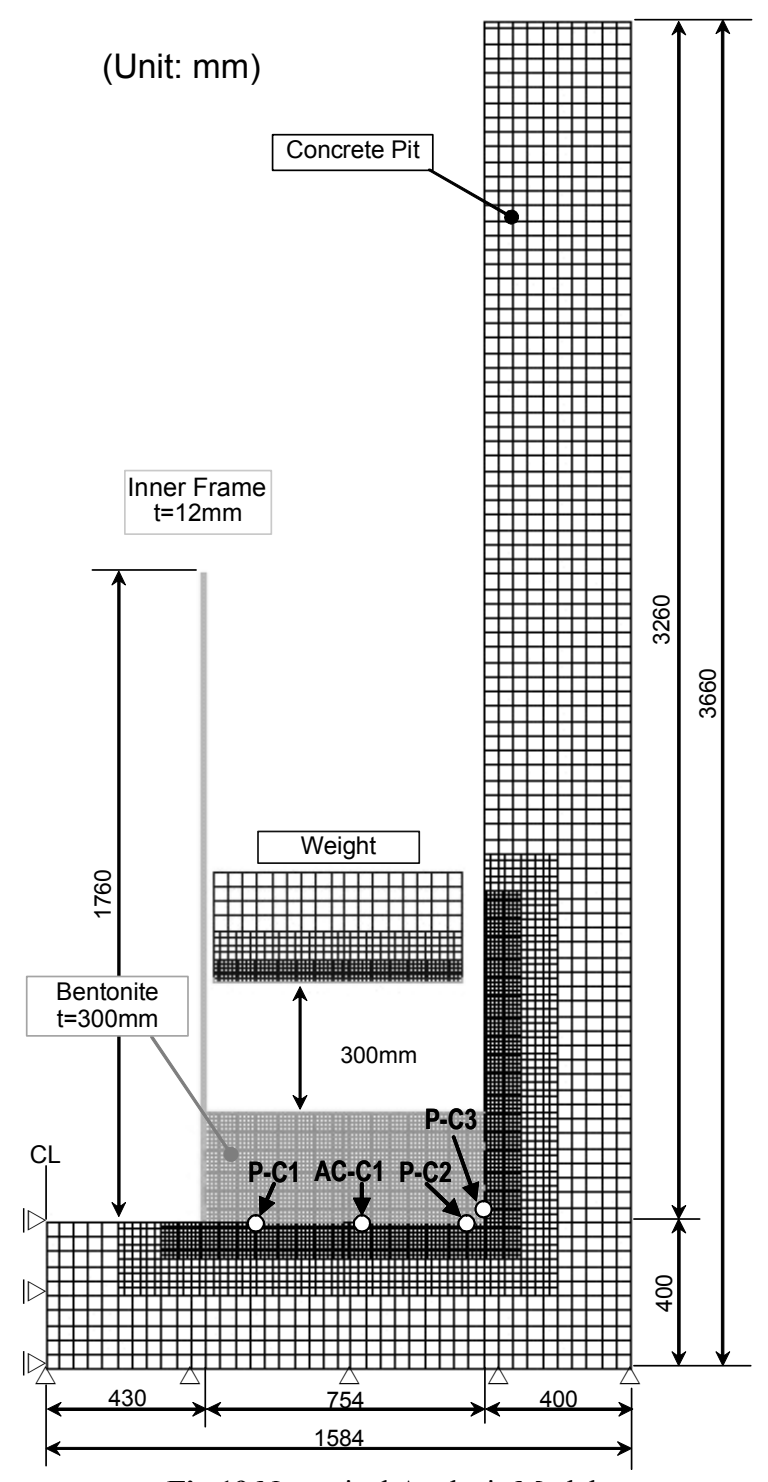

Fig.19 Numerical Analysis Model

\section{(4) Result}

Samples of pressure and acceleration output from the analysis are shown in Fig.20. Table 10 shows a comparison of pressure and acceleration at each output point with measured peak values. For the analysis, the results under conditions disregarding damping $\left(\alpha_{\mathrm{R}}=0, \beta_{\mathrm{R}}=0\right)$ were also shown for reference purposes. Table 10 shows relatively consistent pressure output in both cases $(100 \mathrm{~mm}$ and $300 \mathrm{~mm}$ of buffer material thickness), while acceleration output shows a value of approximately one order of magnitude greater in the case where damping is disregarded. On the other hand, when damping was taken into account, although pressure output shows a high consistency as in the former case, the acceleration output tended to be smaller compared with the measured value. The downward acceleration, which is considered to be an issue for the evaluation, constitutes approximately half of the measured value. In analysis without consideration of damping, as buffer material is plastic, buffer material continues to 

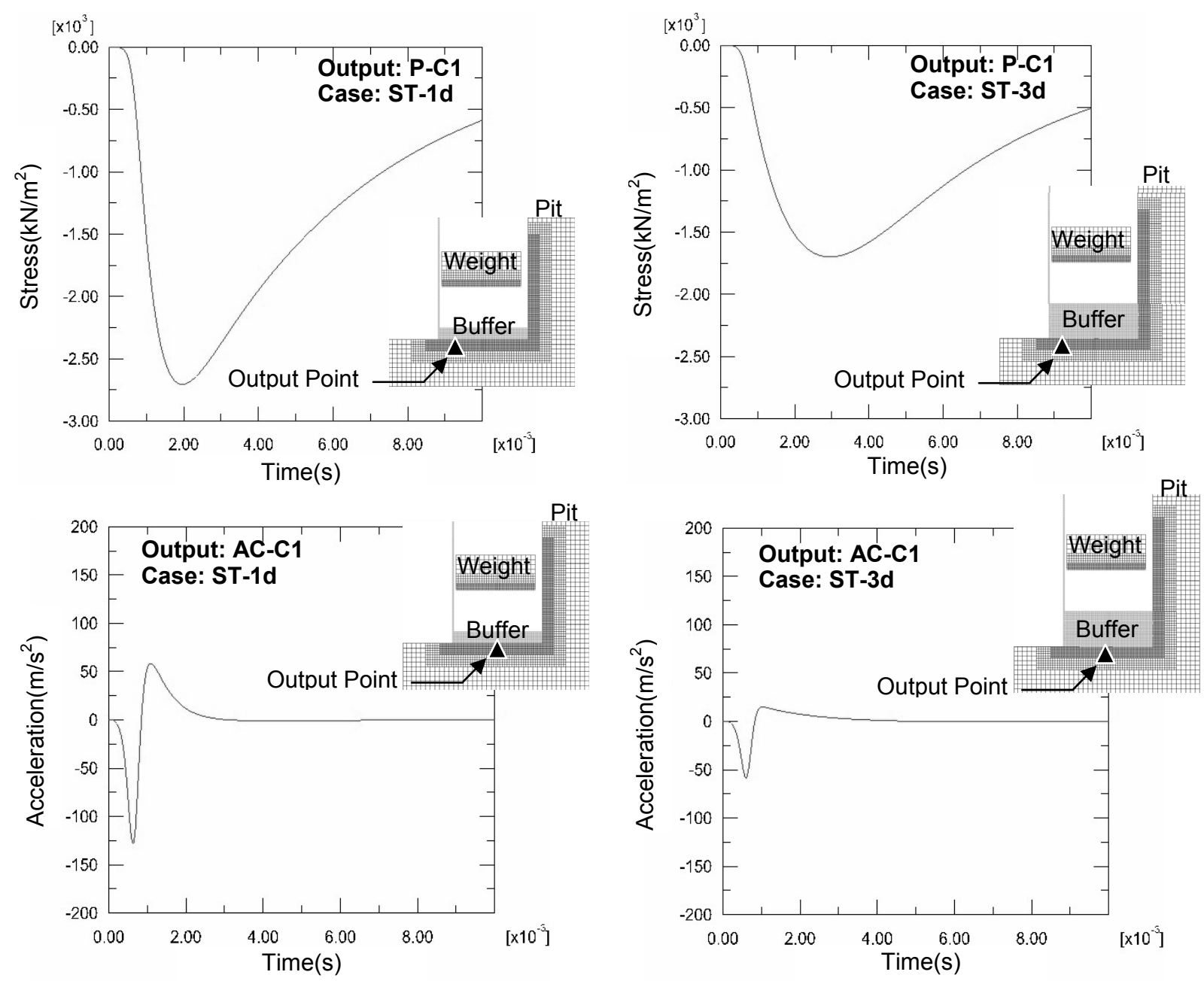

Fig.20 Samples of Acceleration and Pressure Output from Analysis

Table 10 Comparison of Data Obtained from Analysis and Measurement

\begin{tabular}{|c|c|c|c|c|c|c|c|c|}
\hline \multirow[b]{2}{*}{ Item } & \multirow{2}{*}{$\begin{array}{l}\text { Output } \\
\text { Point }\end{array}$} & \multirow[b]{2}{*}{ Direction } & \multicolumn{3}{|c|}{ Buffer $100 \mathrm{~mm} \times 1$ Layer } & \multicolumn{3}{|c|}{ Buffer $100 \mathrm{~mm} \times 3$ Layers } \\
\hline & & & $\begin{array}{c}\text { Measured } \\
\text { Value }\end{array}$ & $\begin{array}{l}\text { Analysis } \\
\text { ST-1nd } \\
\end{array}$ & $\begin{array}{c}\text { Analysis } \\
\text { ST-1d }\end{array}$ & $\begin{array}{c}\text { Measured } \\
\text { Value }\end{array}$ & $\begin{array}{l}\text { Analysis } \\
\text { ST-3nd }\end{array}$ & $\begin{array}{c}\text { Analysis } \\
\text { ST-3d } \\
\end{array}$ \\
\hline \multirow{2}{*}{$\begin{array}{c}\text { Acceleration } \\
(\mathrm{G})\end{array}$} & \multirow{2}{*}{$\mathrm{AC}-\mathrm{C} 1$} & Upward & 14.6 & 200 & 6.0 & 11.1 & 85 & 1.5 \\
\hline & & Downward & 25.7 & 233 & 13.0 & 13.0 & 91 & 6.0 \\
\hline \multirow{3}{*}{$\begin{array}{l}\text { Pressure } \\
(\mathrm{MPa})\end{array}$} & $\mathrm{P}-\mathrm{C} 1$ & Compaction & 2.74 & 2.6 & 2.70 & 1.37 & 1.25 & 1.7 \\
\hline & $\mathrm{P}-\mathrm{C} 2$ & Compaction & 2.31 & 1.86 & 1.33 & 1.50 & 1.16 & 0.97 \\
\hline & P-C3 & Compaction & 1.06 & 1.37 & 1.29 & 0.95 & 0.99 & 1.00 \\
\hline
\end{tabular}

vibrate permanently due to energy obtained from Weight dropping. On the other hand, in consideration of damping, as effect of damping starts when Weight contacts on buffer material, the first peak of acceleration waveform is smaller than the one without consideration of damping. Therefore, it is concluded that results of analysis in consideration of damping is closer to the experiment results than the one without consideration of damping. As analysis results, such as pressure and acceleration occurring in concrete, and the fact that consideration of damping is closer to results of experiment than the one without consideration of damping. Therefore, it is concluded that method of analysis in consideration of damping is more effective than the one without consideration of damping. As possible causes for the minimal acceleration output, we note: (1) the boundary conditions between the buffer and the concrete pit as well as the concrete pit exterior are different from the actual contact conditions, (2) only a rough damping constant was provided for this study, and (3) the strain velocity dependence of the buffer material properties was not taken into consideration. The accuracy of the analysis is expected to improve by accumulating test data for the buffer material properties and damping characteristics, as well as by optimizing various parameters.

The experiment verified that the FEM analysis using Rayleigh damping allows an approximate estimation to be made of pressure and acceleration acting on the buffer material during dynamic compaction, and that it is valid for making an impact 
effect analysis for compaction. In addition to improving accuracy by detailed analysis of the damping constant and optimization of the analysis model, it will be necessary to establish a method for evaluating the rock integrity, overpack and vitrified waste affected by pressure and acceleration due to compaction impact.

\section{CONCLUSION}

The following conclusions were drawn from this study;

(1) Data for acceleration damping characteristics of the buffer material was obtained, and indicates a highly consistent acceleration damping ratio regardless of buffer material specifications or striking energy (compaction energy per strike). Thus, the acceleration damping characteristics of the buffer material were found to have little dependence on dry density, silicate sand mixing ratio and water content of the buffer material or on striking energy within the range of conditions applied in this experiment.

(2) The inverse analysis of the Rayleigh damping constant of the buffer material based on the result of the experiment on buffer material acceleration damping characteristics suggests $\alpha_{\mathrm{R}}=0.0$ and $\beta_{\mathrm{R}}=0.005$ as a highly consistent damping constant.

(3) In order to evaluate effects on surrounding structures during compaction of the actual buffer material, an analysis model simulating experiment was developed. The applicability of the analysis model, which takes Rayleigh damping into account, was examined by comparing measured data for pressure and acceleration obtained from a full-scale experiment with the analytical values. In the analysis disregarding the damping, the acceleration output tended to be approximately one order higher, but the accuracy of the evaluation could be improved by taking the damping into account in the analysis. As a result, the validity of the analytical compaction impact effect analysis on surrounding structures which employs the Rayleigh damping was demonstrated for buffer material compaction. Therefore, regarding future problems, it is necessary to improve analytical accuracy by review of analytical parameters. In addition, it is necessary to incorporate a constitutive equation into the analytical model, and which defines compaction behavior of buffer material, which is thought to be non-liner elasto-plastic behavior.
Note: This paper is a summary of part of the outcome of "Study on Remote Operation Technology at HLW Repository" commissioned by the Ministry of Economy, Trade and Industry.

\section{REFERENCES}

1) Radioactive Waste Management Funding and Research Center: Study on Remote Operation Technology at HLW Repository, 4.3.2 Concept Design of Handling, Emplacement and Retrievability, pp.4-143-4-757, 2001. [in Japanese].

2) Masuda, R., Asano, E., Amemiya, K., Chijimatsu, M., Komine, H. and Adachi, K.: Study on Dynamic Compaction of a Buffer Material Mixed with Bentonite for HLW Final Disposal, Journals of the Japan Society of Civil Engineers, No.764 / III-67, pp.329 340, 2004. [in Japanese with English abstract].

3) Masuda, R., Amemiya, K., Chijimatsu, M., Komine, H. and Adachi, K.: Study on the Influence of a Specification of Buffer Material on the Compaction Characteristics, Journals of the Japan Society of Civil Engineers, No.771/III-68, pp.157 171, 2004. [in Japanese with English abstract].

4) Radioactive Waste Management Funding and Research Center: Study on Remote Operation Technology at HLW Repository, 3.1.2 Study on the Emplacement Technology of Bentonite Block Buffer, pp.3-34 3-259, 2003. [in Japanese].

5) The Japanese Geotechnical Society: Means and Description of Soil Experiment, pp.252 263, 2000. [in Japanese].

6) Nishimura, T., Ono, F. and Masuda, R.:Study on the In-situ Compaction Method for Bentonite Buffer - Study on the Damage of a Rock on Striking of Compaction-, 55th JSCE Annual Meeting, CS-194, 2000. [in Japanese].

7) Japan Nuclear Cycle Development Institute: H12:Project to Establish the Scientific and Technical Basis for HLW Disposal in Japan / Supporting Report 2, 4.1.2.3 Design of the Buffer, pp.IV-69 IV-81, 2000.

8) Radioactive Waste Management Funding and Research Center: Study on Remote Operation Technology at HLW Repository, 4.3.2 Concept Design of Handling, Emplacement and Retrievability, pp.4-559-4-648, 2001. [in Japanese].

9) Toki, K.: New edition of civil engineering, The earthquake-proof design of a structure, 3.1.2 Damping Matrix, pp.134 137, Gihodo Publishing, 1981. [in Japanese].

10) Masuda, R., Asano, E., Amemiya, K., Moro, Y., Kosuge, K. and Komine, H.: Study on In-situ Compaction Method for Bentonite Buffer by Means of Full-Scale Compaction Test, Journals of the Japan Society of Civil Engineers, No.777/ VI-65, pp.59 72, 2004. [in Japanese with English abstract].

11) Japan Society of Civil Engineers: JSCE Guidelines for Concrete No.3, STANDARD SPECIFICATIONS FOR CONCRETE STRUCTURES-2002, Structural Performance Verification., pp.249-251, 2002. [in Japanese]

(Received February 8, 2005) 